\title{
The Shifting Determinants of DefEnse SPENDing PREFERENCES BETWEEN 1980 AND 2008
}

\author{
A Thesis \\ submitted to the Faculty of the \\ Graduate School of Arts and Sciences \\ at Georgetown University \\ in partial fulfillment of the requirements for the \\ degree of \\ Master of Public Policy \\ in the Georgetown Public Policy Institute
}

By

Nicholas J. Veasey, B.S.

Washington, D.C.

April 15, 2010 
Copyright 2010 by Nicholas J. Veasey

All Rights Reserved 


\title{
The Shifting Determinants of Defense Spending Preferences BETWEEN 1980 AND 2008
}

\author{
Nicholas J. Veasey, B.S.
}

Thesis Advisor: Sencer Ecer, Ph.D.

\begin{abstract}
It has been well documented that public opinion is a crucial driver of defense spending; however, the determinants of the public's defense spending preferences have changed throughout the years. Using regression analysis and the most recently released American National Election Survey data from 1980 through 2008, this thesis evaluates the role political party identification and other relevant variables have played in defense spending preferences. In general, during the 1980 s, political party identification played a large role in an individual's defense spending preferences. In the 1990s, this trend seemed to begin to dissipate as politics took a back seat to other less partisan factors such as education, marital status, and other demographic factors. Defying predictions by scholars, in the 2000s, the pendulum swung back and politics became an even stronger determinant of defense spending preferences then it had been in the 1980s.
\end{abstract}




\section{Acknowledgements}

First and foremost, I would like to thank Doctor Sencer Ecer for his time, understanding, and patience throughout the entire Thesis process. Without his help and insightful guidance, this thesis would not have been possible. I could not have asked for a better thesis advisor.

Additionally, I would like to thank Lisa Orlowski for her help along the way. Whether it was late-night numbers reading from the Almanac of American Politics to help me establish my "economic stake" variable or simply brainstorming ideas to keep me on track and focused, her help and encouragement will not be forgotten.

Finally, I would like to thank my parents, for without their support, I would never have made it this far. My father, Robert, gave me an analytical edge and the indefatigable encouragement young men oftentimes need. My mother, Margo, inspired me emotionally, taught me to love and care, and has served as the most reliable rolemodel I know throughout countless situations in life.

Many thanks,

NiCHOLAS J. VEASEY 


\section{Table of Contents}

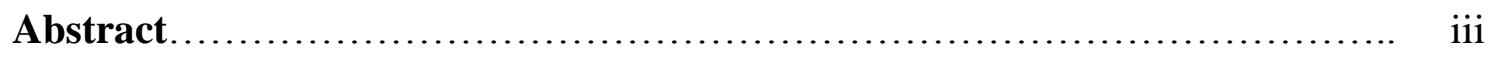

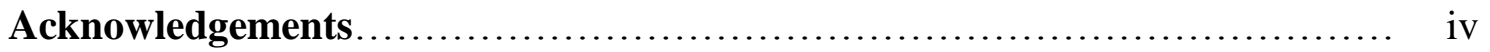

List of Tables and Charts ................................................... v

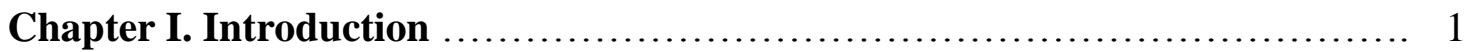

Chapter II. Literature Review .......................................... 2

American Public's Defense Spending Preferences in the Post-Cold War Era ........ 2

Political Economy of Military Spending in the United States ...................... 4

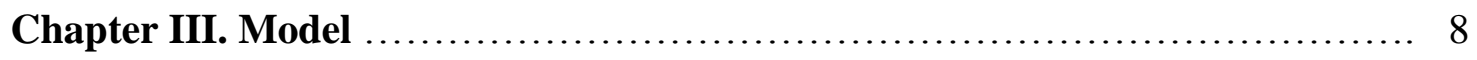

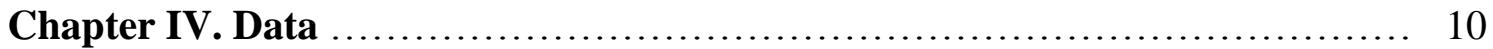

Defense Spending Preferences Variable .................................... 11

Isolationist Variable ....................................................... 15

Determinants of Isolationism Variable ................................... 17

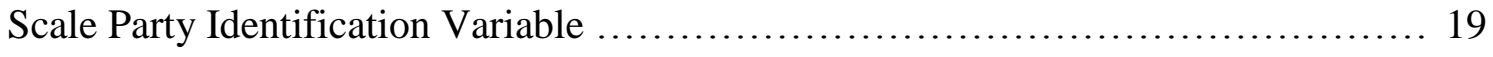

Determinants of Scale Party Identification Variable ........................ 21

Economic Stake Variables ......................................................... 23

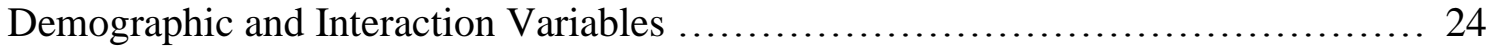

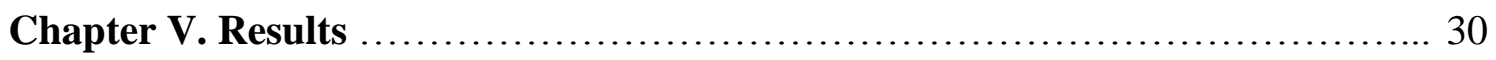

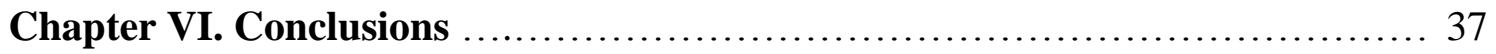

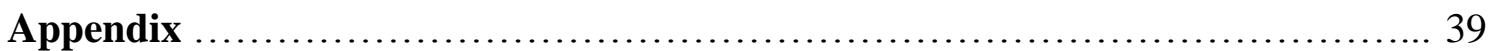




\section{List of Tables and Charts}

\section{Charts and figures}

Chart 1 Average Defense Spending Preferences from 1980 - 2008 .............. 15

Chart 2 Average Proportion of Isolationists from $1980-2008$................... 17

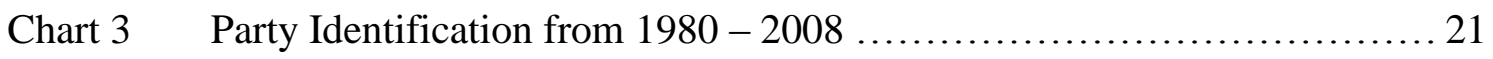

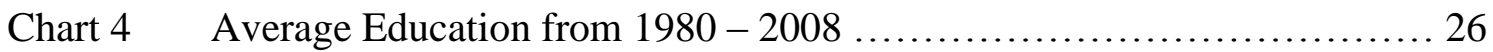

Figure 5 Employment Status Descriptive Statistics ........................... 27

Figure 6 Race Descriptive Statistics .................................... 28

Figure 7 Interaction Variable Descriptive Statistics ............................ 29

\section{Tables}

Table $1 \quad$ U.S. Spending on National Defense................................. 14

Table 2 Isolationist Regression with Variables of Interest...................... 18

Table 3 Scale Party Identification Regression with Variables of Interest...........22

Table 4 Defense Spending Preferences Regression........................... 30

Table 5 Defense Spending Preferences Regression 1980s - 1990s................ 34

Table 6 Defense Spending Preferences Regression 1990s - 2000s .............. 35

Table $7 \quad$ Economic Stake Compilation Example 1984 ............................39

Table 8 Economic Stake ............................................ 40 


\section{Chapter I. Introduction}

Public opinion on defense spending has changed widely through the years and it has been shown to have a statistically significant impact on policy outcomes. ${ }^{1}$

Researchers spent a significant amount of time studying the determinants of public opinion on defense spending at the end of the Cold War. While many of these determinants have not changed, the Soviet Union is no longer a major factor in our defense spending preferences - as it was during the Cold War. Additionally, in the aftermath of September $11^{\text {th }}, 2001$, we have entered into a new security environment that holds the constant threat of terrorism. Hence, public opinion on defense spending has likely changed since the end of the Cold War and deserves to be revisited.

I use a variation of several modeling frameworks built throughout numerous years of academic research on defense spending preferences and I incorporated the most recent data from the American National Election Studies (ANES) cumulative data file along with the ANES 2008 panel data that was released in 2009. Some academics concluded that politics had become less of a determining factor on defense spending preferences since the end of the cold war and that "willingness to use force" and "isolationism" variables had become the new driving force behind defense spending preferences. In this thesis I attempt to show that an individual's political party identification, once again, played a large role in defense preferences in the 2000s.

\footnotetext{
1 Bartels, 1994.

Russett, Hartley, Murray, 1992.

Higgs, Kilduff, 1993.
} 


\section{Chapter II. Literature Review}

Since President Dwight D. Eisenhower coined the phrase, "the military-industrial complex,"2 in his farewell speech in 1961, scores of academic papers and books have evaluated the sources and uses of money the United States has spent on defense. Academics have looked at the impact of defense spending on growth and unemployment at the state level, political influence over defense procurement, the role of defense spending in redistribution and inequality among countless other topics. Since this paper focuses on public opinion as a main driver of the amount spent on defense, I focused the literature review on two books: (a) The Political Economy of Military Spending in the United States - a collection of essays on defense spending - and (b) The Rational Public. Additionally, the following papers greatly aided my understanding of the topic and helped guide my research: (a) The American Public's Defense Spending Preferences in the Post-Cold War Era, (b) Public Opinion and the Common Defense: Who Governs Military Spending in the United States?, (c) Public Opinion: A Powerful Predictor of U.S. Defense Spending, and (d) Constituency Opinion and Congressional Policy Making: The Reagan Defense Buildup. I discuss this academic literature in detail below.

\section{American Public's Defense Spending Preferences in the Post-Cold War Era}

In Larry Bartels’ paper “The American Public's Defense Spending Preferences in the Post-Cold War Era," he uses public opinion data from the American National

\footnotetext{
${ }^{2}$ Eisenhower, 1961.
} 
Election Studies to ascertain the determinants of defense spending preferences immediately following the dissolution of the Soviet Union. His results show that "defense spending preferences were determined more by a predisposition to favor or oppose the use of force in the international arena than by either general political ideology or attitudes toward the Soviet Union per se." along with whether or not an individual considers him or herself to be an "isolationist" was the driving factor in determining an individual's defense spending preference.

Another finding of the Bartels' paper is that informed voters were quicker to change their defense spending preferences following the end of the Cold War than uninformed voters. While attempting to control for the amount of money individuals stand to gain from Department of Defense budgetary spending in their state, Bartels' creates an "Economic Stake" variable (explained in depth in the Data Section of this paper), which I used in my own model. Bartels' paper pooled semi-annual data from the period 1980 - 1992 to ascertain the determinants of American defense spending preferences and he controls for individual years with a dummy variable. His model is presented below:

Defense Spending Preferences $=$ $\beta_{0}+\beta_{1}$ Conservative ideology $+\beta_{2}$ Toughness toward Russia (1984) $+\beta_{3}$ Willingness to use force $+\beta_{4}$ Isolationism $(1980-88)+\beta_{5}$ Economic Stake.

\footnotetext{
${ }^{3}$ Bartels, 485.
} 
I will now turn to other public opinion polling and defense spending preference issues that must be addressed in order to construct my model. The Political Economy of Military Spending in the United States - a collection of essays compiled and edited by Alex Mintz - provides an excellent background on issues surrounding defense spending.

\section{Political Economy of Military Spending in the United States}

In his essay, "The Political Economy of Military Spending in the United States", Richard Stoll takes on the critique that American public opinion on defense spending is "fickle, changeable and susceptible to wide fluctuations without any underlying rational." While leaving open the possibility of public opinion being changed by substantial events, Stoll points out that defense spending preferences have held relatively steady throughout time with extreme opinions on both sides balancing each other out. Additionally he shows that any form of strong public consensus on defense spending has had a noticeable impact on the budget process. For his analysis of the proportion of public that feel current defense spending is too little, Stoll uses the following model:

Defense spending too little $=$ $\beta_{0}+\beta_{1}$ Number of visible uses of force involving USSR during war (per year) + $\beta_{2}$ number of visible uses of force involving USSR during peace (per year) $+\beta_{3}$ Previous defense spending $+\beta_{4}$ Previous level of support for increased defense spending $+\beta_{5}$ Impact of the Reagan administration. 
Prior year defense spending and both visible uses of force variables had a statistically significant effect. His results showed that a small number of factors had a large impact on public opinion of defense spending and that these factors make it difficult to sustain a perpetual rise in defense spending. ${ }^{4}$

The importance of public opinion on defense spending is also stressed in a joint article written by Bruce Russett, Thomas Hartley, and Shoon Murray at Yale University. The authors claim, "public opinion is the most substantively important influence on the budget that remains after the Cold War." opinion, the amount of deficit spending, and the declining threat of the Soviet Union. Additionally, the authors find that while public opinion affects defense-spending preferences, the opposite is not true; as defense spending increases or decreases, public opinion does not closely track those changes. This finding is important for my thesis because reverse causalities affect the strength of econometric modeling. The direction of causal effect between public opinion and defense spending is also evaluated in the following paper.

In their paper "Public Opinion: A Powerful Predictor of U.S. Defense Spending", Robert Higgs and Anthony Kilduff constructed a variable called the "Opinion Balance" by subtracting the percentage of those who favor less defense spending from the percentage of those who favor more defense spending. Using a variable called the residuum, to control for the percentage of people who wanted the status quo defense spending, they find that the "Opinion Balance" is an accurate predictor of U.S. defense

${ }^{4}$ Mintz, 1992.

${ }^{5}$ Russett, Hartley and Murray, 1994. 
spending. Higgs and Kilduff also used a Granger test to evaluate causality between growth in U.S. defense spending outlays and public opinion on defense spending. They concluded that public opinion - at a fairly high level of confidence - did cause outlay growth, but that the reverse was not true.

Oscar Torres-Reyna and Robert Shapiro's paper, “The Polls - Trends: Defense and the Military", gives the reader an in depth look at defense spending preferences from the 1960s onward. The paper identifies and explains major shifts in defense spending preferences including the low point at the end of the Vietnam War through the high points of the Reagan administration, the subsequent pullback at the end of the cold war and the 31-point swing in defense spending preferences in the wake of September $11^{\text {th }}$, 2001. Their paper does not attempt to explain defense spending preferences with regression analysis, but it does investigate budget trade-offs for defense spending. Not surprisingly, when the United States is not involved in armed conflict overseas, growing majorities approve cutting defense spending to reduce the budget deficit. While many Americans benefit from defense spending, the budget deficit is never far from the mind of most Americans.

In "Predispositions and Public Support for the President During the War on Terrorism," Jonathan Ladd uses panel data from 2000 - 2002 ANES survey to examine how changes in presidential approval are related to defense policy predispositions and prior political awareness. His results show that people with "different levels of political awareness will respond to dramatic messages in distinct ways." While Ladd makes the case that political party identification became less of a determining factor in evaluations 
of President Bush between 2000 and 2002, he mentions that political party identification should be included when evaluating defense spending preferences due to the possibility of omitted variable bias if political party identification is not included. Ladd's paper also cites Hurwitz and Peffley's 1987 paper as support for including political party identification in models that examine defense spending preferences. Therefore, although Bartels argues that politics will play less of a role in defense spending preferences, I have decided to include political party identification in my model.

The academic literature reviewed above guided my thinking when developing a model for this thesis. Bartels' model served as my starting point, but his model was designed to evaluate changes in defense spending preferences following the Cold War and includes a control variable for the influence Russia had on U.S. defense spending. His paper also points towards the declining influence of political party identification on defense spending preferences. Ladd's paper indicates that political party identification does, in fact, have an influence on defense spending preferences and he argues for the inclusion of a control variable.

Defense spending has been studied from many different angles throughout the years. In this thesis, my goal is to evaluate how the determinants of individual's defense spending preferences have changed from 1980 through 2008. 


\section{Chapter III. Model}

Having seen that public opinion has been a strong driver of defense spending and evaluated several models for defense spending preferences, I have constructed my model to include my main variables of interest and a group of demographic variables to control for the impact of various other demographic and socio-economic factors such as age, race, education, marital status, gender and employment status. The model also includes a group of dummy variables to control for the individual year of the study as well as two interaction variables of interest:

Defense Spending Preferences $=$ $\beta_{0}+\beta_{1}$ Isolationist $+\beta_{2}$ Scale Political Party Identification $+\beta_{3}$ Economic Stake $+\beta_{4}$ Married $+\beta_{5}$ Female $+\beta_{6}$ Age $+\beta_{7}$ Education $+\beta_{8}$ Unemployed $+\beta_{9}$ Retired $+\beta_{10}$ Not Working $+\beta_{11}$ Black $+\beta_{12}$ Asian $+\beta_{13}$ Native American $+\beta_{14}$ Hispanic $+\beta_{15}$ Other Race $+\beta_{16}$ Dummy Variables to Control for Year (1980 - 2004 with 2008 as the baseline $)+$ $\beta_{17}$ Security Moms (Security * $+\beta_{18}$ Retired Women

Based on the literature to date, I expect the Isolationist dummy variable to have a strong negative correlation with defense spending preferences. In addition, I expect a strong positive correlation between defense spending preferences and scale political party identification - a high score on the political party identification is "very Republican". I also expect the economic stake variable to have a positive correlation. Finally, previous 
literature has shown that an individual's education level will have a strong negative correlation with defense spending preferences and that being female has a negative correlation with the dependent variable. With regards to the interaction variables, I expect a positive coefficient on security moms and a negative coefficient on retired women based on the underlying dummy variables. 


\section{Chapter IV. Data}

The Cumulative Data File (CDF) taken from the American National Election Studies website is a compilation of time series data from the Pre-/Post-Election Study in presidential election years and the Post-Election Study in midterm years. "The CDF is pooled cross- section studies: any respondent for a particular study who is strictly "panel" or "supplement" has been deleted from the Cumulative File." For the purposes of this thesis, I have used data from the CDF for the years 1980 - 2004. Since the 2008 ANES survey has not yet been incorporated into the CDF and I wanted to use the most up to date information, I went through the process of recoding all the 2008 main variables of interest as well as the wealth of demographic and socio-economic data described below. In certain instances, the 2008 ANES question phrasing was different than the CDF. In other instances, the list of possible answers from which the respondent could choose was different than the list of answers used in the CDF. In all cases where there were discrepancies between the 2008 data and the CDF, I listed the discrepancy and the method I used to correct the discrepancy in the following sections.

Public opinion polling, of course, has its inevitable downfalls. Even though several of our main variables of interest were asked during all of the years in our study, the survey question placement varied from year to year and could have had an effect on the overall results. While most respondents pay close attention in the beginning of a survey, it is conceivable that their minds could wonder as the session goes on. Additionally, the American National Election Studies survey was conducted in person in 
certain years and via telephone for portions of other years. While question placement and type of interview method concerns could be cause for concern, prior research using the ANES data has concluded that data sensitivity for these two issues does not pose a significant bias. ${ }^{6}$

\section{Defense Spending Preferences Variable}

The Defense Spending Preferences Variable is constructed from a single question in the ANES cumulative data file and two different questions in the ANES 2008 survey. The data ranges from 1980 through 2008 and the surveys were taken on presidential election years in the 2000s and congressional election years (every two years) in the 1980s and 1990s. In total, 19,043 observations were taken for the defense spending preferences variable through the years in my study.

For 1980, 1982, 1984, 1986, 1988, 1990, 1992, 1994, 1996, 2000, and 2004 the question read as follows:

Some people believe that we should spend much less money for defense. Others feel that defense spending should be greatly increased. Where would you place yourself on this scale or haven't you thought much about this?

The respondent was then given a 7-point scale to choose from:

1. Greatly decrease defense spending

\footnotetext{
${ }^{6}$ Ladd, 2007.
} 
2. Somewhat decrease defense spending

3. Slightly decrease defense spending

4. About right

5. Slightly increase defense spending

6. Somewhat increase defense spending

7. Greatly increase defense spending.

9. DK; haven't thought much about it

In 2008, 963 of the respondents were randomly assigned to the old defense spending preferences question with the old responses (listed above). However, the remaining 1,120 respondents were given the "new" question and responses to choose from which are listed below:

Do you think that government should spend more on national defense, less on national defense, or about the same on national defense now?

The respondent was then given a 7-point scale to choose from (note that the order of preferences in the "new" survey was reversed from the "old" survey):

1. A lot more

2. Somewhat more

3. Slightly more

4. About the same

5. Slightly less

6. Somewhat less

7. A lot less

-1. INAP,

-8. Don't know

-9. Refused 
For the new survey, I recoded the 1-7 defense spending preference scale to match the variable in the CDF and the old version of the defense spending preferences survey (1 - greatly decrease and 7 - greatly increase). Additionally, I changed all the "don't know", "refused", "INAP”, and "haven't thought much about it" responses to missing for the purposes of my regressions.

From 1980 through 2008, the responses vary a great deal. Chart 1 (below) shows the average response on the 7-point scale and the standard deviation per year. The mean response starts high at 5.21 and slowly falls (with one exception) until it hits a low of 3.50 in 1992 . The standard deviation is relatively high which speaks to the diverse public opinions on levels of defense spending. In the three years where the standard deviation is lowest - indicating the least disagreement on defense spending preferences - we see a variety of defense spending preferences (also see Table 1 for U.S. defense spending):

1. The 1980 desire for increased spending preferences swept Reagan into office on a campaign platform of increased military spending.

2. In 2000, Bush was elected after 8 years of Democratic Presidential control that saw the defense budget shrink in comparison with other domestic programs.

3. In 2008, the defense spending preferences dropped sharply as Americans became disenfranchised with being involved in wars in Iraq and Afghanistan. Obama was elected on promises of ending the war in Iraq and focusing on domestic and international programs other than defense. 
Table 1: U.S. Spending on National Defense

\begin{tabular}{|c|c|c|c|c|}
\hline $\begin{array}{l}\text { Fiscal } \\
\text { Year }\end{array}$ & $\begin{array}{r}\text { Defense Spending } \\
\text { (\$ in billions) }\end{array}$ & $\begin{array}{r}\text { As \% } \\
\text { of outlays }\end{array}$ & $\begin{array}{r}\text { As \% } \\
\text { of GDP }\end{array}$ & President \\
\hline 1980 & $\$ 134.0$ & $22.7 \%$ & $4.9 \%$ & Reagan \\
\hline 1981 & 157.5 & $23.2 \%$ & $5.2 \%$ & " \\
\hline 1982 & 185.3 & $24.8 \%$ & $5.7 \%$ & $"$ \\
\hline 1983 & 209.9 & $26.0 \%$ & $6.1 \%$ & $"$ \\
\hline 1984 & 227.4 & $26.7 \%$ & $5.9 \%$ & $"$ \\
\hline 1985 & 252.7 & $26.7 \%$ & $6.1 \%$ & $"$ \\
\hline 1986 & 273.4 & $27.6 \%$ & $6.2 \%$ & $"$ \\
\hline 1987 & 282.0 & $28.1 \%$ & $6.1 \%$ & $"$ \\
\hline 1988 & 290.4 & $27.3 \%$ & $5.8 \%$ & $"$ \\
\hline 1989 & 303.6 & $26.5 \%$ & $5.6 \%$ & H.W. Bush \\
\hline 1990 & 299.3 & $23.9 \%$ & $5.2 \%$ & $"$ \\
\hline 1991 & 273.3 & $20.6 \%$ & $4.6 \%$ & $"$ \\
\hline 1992 & 298.4 & $21.6 \%$ & $4.8 \%$ & $"$ \\
\hline 1993 & 291.1 & $20.7 \%$ & $4.4 \%$ & Clinton \\
\hline 1994 & 281.6 & $19.3 \%$ & $4.0 \%$ & $"$ \\
\hline 1995 & 272.1 & $17.9 \%$ & $3.7 \%$ & $"$ \\
\hline 1996 & 265.8 & $17.0 \%$ & $3.4 \%$ & $"$ \\
\hline 1997 & 270.5 & $16.9 \%$ & $3.3 \%$ & $"$ \\
\hline 1998 & 268.2 & $16.2 \%$ & $3.1 \%$ & $"$ \\
\hline 1999 & 274.8 & $16.1 \%$ & $3.0 \%$ & $"$ \\
\hline 2000 & 294.4 & $16.5 \%$ & $3.0 \%$ & $"$ \\
\hline 2001 & 304.8 & $16.4 \%$ & $3.0 \%$ & Bush \\
\hline 2002 & 348.5 & $17.3 \%$ & $3.3 \%$ & $"$ \\
\hline 2003 & 404.8 & $18.7 \%$ & $3.7 \%$ & $"$ \\
\hline 2004 & 455.8 & $19.9 \%$ & $3.9 \%$ & $"$ \\
\hline 2005 & 495.3 & $20.0 \%$ & $4.0 \%$ & $"$ \\
\hline 2006 & 521.8 & $19.7 \%$ & $3.9 \%$ & $"$ \\
\hline 2007 & 552.6 & $20.3 \%$ & $4.0 \%$ & $"$ \\
\hline 2008 & 607.3 & $20.4 \%$ & $4.2 \%$ & $"$ \\
\hline
\end{tabular}

1 OMB Historical Tables, Table 3.1: Outlays by superfunction and function: $1940-2013$

2 Budget of the United States Government, Fiscal year 2009 
Chart 1 Average Defense Spending Preferences from 1980-2008

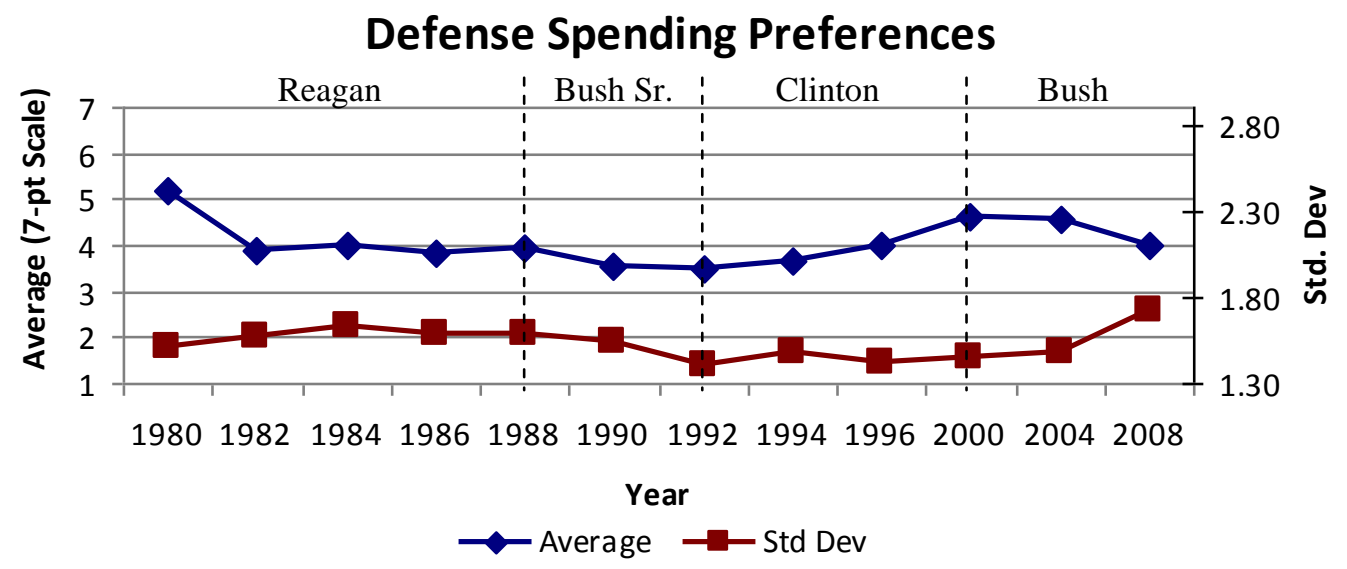

\begin{tabular}{ccc}
\hline Year & Average & Std Dev \\
\hline 1980 & 5.21 & 1.50 \\
1982 & 3.86 & 1.57 \\
1984 & 3.99 & 1.63 \\
1986 & 3.82 & 1.59 \\
1988 & 3.93 & 1.59 \\
1990 & 3.55 & 1.55 \\
1992 & 3.50 & 1.41 \\
1994 & 3.69 & 1.47 \\
1996 & 4.02 & 1.42 \\
2000 & 4.63 & 1.45 \\
2004 & 4.57 & 1.48 \\
2008 & 3.98 & 1.72 \\
& & \\
\hline
\end{tabular}

\section{Isolationist Variable}

The Isolationist variable question has changed throughout the years covered by the American National Election Studies cumulative data file. Since we are using data covering a wide range of dates, it is important to know how the question varied to account for any potential direction bias. The following questions were used in the years 
indicated to track "Isolationist":

1968: Now I'd like to read some of the things people tell us when we interview them (1968: and ask you; 1980: As I read, please tell me) whether you agree or disagree with them.

1972: I'd like you to tell me whether you agree or disagree with each of these next six statements.

1976: I am going to read you two statements about US foreign policy and I would like you to tell me whether you agree or disagree with each statement

1984-1988,1992: I am going to read a statement about US foreign policy, and I would like you to tell me whether you agree or disagree.

1990,1994-LATER: Do you agree or disagree with this statement.

In all years, the statement posed to the respondent was:

This country would be better off if we just stayed home and did not concern ourselves with problems in other parts of the world.

The respondent was then given the scale:

1. Agree

2. Disagree

9. DK; depends; not sure; no opinion, can't say; refused to say

I recoded all those who disagreed with this statement - non-isolationists - as zero in order to create a dummy variable to represent the isolationists. All respondents who answered 9 were recoded as missing for the purposes of this study and prior research using the ANES has determined that potential direction bias does not exist for the variations of the isolationist variable. 
Chart 2 Average Proportion of Isolationists from 1980-2008

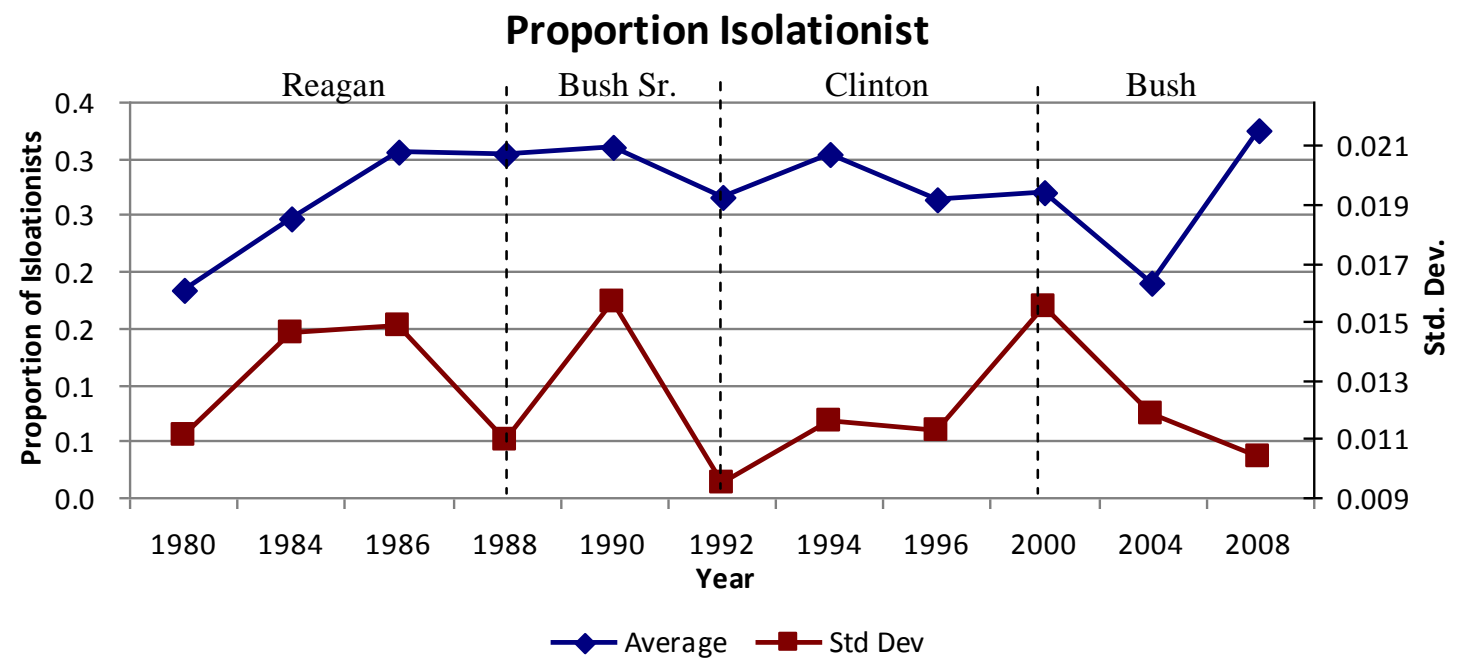

\begin{tabular}{ccc}
\hline Year & Average & Std Dev \\
\hline 1980 & 0.18 & 0.0106 \\
1984 & 0.25 & 0.0141 \\
1986 & 0.31 & 0.0144 \\
1988 & 0.30 & 0.0104 \\
1990 & 0.31 & 0.0151 \\
1992 & 0.27 & 0.0090 \\
1994 & 0.30 & 0.0111 \\
1996 & 0.26 & 0.0107 \\
2000 & 0.27 & 0.0150 \\
2004 & 0.19 & 0.0113 \\
2008 & 0.32 & 0.0099 \\
\hline
\end{tabular}

\section{Determinants of the Isolationism Variable}

Since an individual's feelings towards isolationism play a large part in their defense spending preferences, understanding the determinants of the isolationism variable allow for a deeper understanding of an individual's overall defense spending preferences. In this section, I used the isolationist dummy variable as the dependent variable and 
regressed the other main variables of interest upon the isolationist variable. The results are listed in Table 2 with the statistically significant (P-values < 10\%) variables in bold:

Table 2: Isolationist Regression with Variables of Interest

\begin{tabular}{|c|c|c|c|c|}
\hline Independent Variables & Coef. & St. Err. & T-Value & P-Value \\
\hline scalepartyid & -0.0131 & 0.002 & -7.64 & 0.000 \\
\hline econstake & 0.0000 & 0.000 & -1.28 & 0.201 \\
\hline married & -0.0258 & 0.008 & -3.18 & 0.001 \\
\hline female & 0.0334 & 0.009 & 3.70 & 0.000 \\
\hline age & -0.0005 & 0.000 & -1.62 & 0.105 \\
\hline educ & -0.0886 & 0.004 & -24.99 & 0.000 \\
\hline unemployed & 0.0062 & 0.016 & 0.38 & 0.704 \\
\hline retired & 0.0658 & 0.017 & 3.94 & 0.000 \\
\hline notworking & 0.0223 & 0.011 & 2.08 & 0.037 \\
\hline black & 0.0035 & 0.011 & 0.30 & 0.762 \\
\hline asian & -0.0069 & 0.026 & -0.27 & 0.789 \\
\hline nativeamer $n$ & 0.0291 & 0.022 & 1.33 & 0.183 \\
\hline hispanic & 0.0037 & 0.015 & 0.25 & 0.802 \\
\hline otherrace & -0.1119 & 0.059 & -1.89 & 0.059 \\
\hline fy1980 & -0.1526 & 0.015 & -10.12 & 0.000 \\
\hline fy1984 & -0.0821 & 0.018 & -4.67 & 0.000 \\
\hline fy1986 & -0.0287 & 0.018 & -1.62 & 0.105 \\
\hline fy1988 & -0.0246 & 0.015 & -1.66 & 0.097 \\
\hline fy1990 & -0.0340 & 0.018 & -1.86 & 0.063 \\
\hline fy1992 & -0.0541 & 0.014 & -3.89 & 0.000 \\
\hline fy1994 & -0.0033 & 0.015 & -0.22 & 0.829 \\
\hline fy1996 & -0.0425 & 0.015 & -2.84 & 0.004 \\
\hline fy2000 & -0.0260 & 0.018 & -1.42 & 0.155 \\
\hline fy2004 & -0.1112 & 0.015 & -7.21 & 0.000 \\
\hline securitymoms & -0.0033 & 0.013 & -0.25 & 0.799 \\
\hline retiredWomen & -0.0297 & 0.020 & -1.48 & 0.139 \\
\hline cons & 0.5954 & 0.022 & 27.01 & 0.000 \\
\hline
\end{tabular}

As expected, scale party identification is a statistically significant variable with the negative sign indicating that as one becomes more republican on the 7-point scale, one is less likely to be an isolationist. Being married has a negative effect on the 
likelihood of an individual being an isolationist which implies that, all else being equal, married people are $0.93 \%$ less likely to be isolationists after accounting for the effect of the security moms interaction variable.

Increasing education, the most statistically significant variable in this regression, has a strong negative effect on the likelihood of one being an isolationist. The race variables are all statistically insignificant except for "other race" which accounts for only 54 respondents out of a total of more than 22,600 (less than $0.25 \%$ ).

Two interesting results from this regression are the "retired" and "not working" variables. Both variables are statistically significant and have a positive sign indicating that being retired or not working makes you more likely than an employed person to be an isolationist. One possible explanation is that the retired and not working would prefer the U.S. to spend its scarce tax dollars and limited resources within its own borders in comparison with employed people who might feel more secure with the U.S. going overseas to protect its national interests.

\section{Scale Party Identification Variable}

The 7-pt scale party identification variable was asked in each year from 1952 to the present 2008 in the ANES data. The respondent was asked the following question: “Generally speaking, do you usually think of yourself as a Republican, a Democrat, an Independent, or what? (IF REPUBLICAN OR DEMOCRAT) Would you call yourself a strong (REP/DEM) or a not very strong (REP/DEM)? (IF INDEPENDENT, OTHER [1966 AND LATER: OR NO 
PREFERENCE]:) Do you think of yourself as closer to the Republican or

Democratic party?"

The respondent was the placed on the following scale based upon their answers:

1. Strong Democrat

2. Weak Democrat

3. Independent - Democrat

4. Independent - Independent

5. Independent - Republican

6. Weak Republican

7. Strong Republican

9. Apolitical (1966 only: and DK)

In all years, if a respondent answered with the mention of a minor party and then responded 'neither,' DK or NA when asked if s/he felt closer to either major party, then s/he has been coded "other" which was subsequently coded as missing for the purposes of this study.

In 2008, the respondents were asked two separate questions. The first question asked the respondent to identify whether they were a Republican, Democrat, Independent, or did not know / care. The second question asked the respondent to indicate the strength of their political identification. Since the 2008 survey used two separate questions, I had to create a new variable that would include both political identification and strength of political party identification. This new variable then had to be recoded to match the CDF. The information on Chart 3 details the U.S. scale party identification from $1980-2008$. 
Chart 3 Party Identification from $1980-2008$

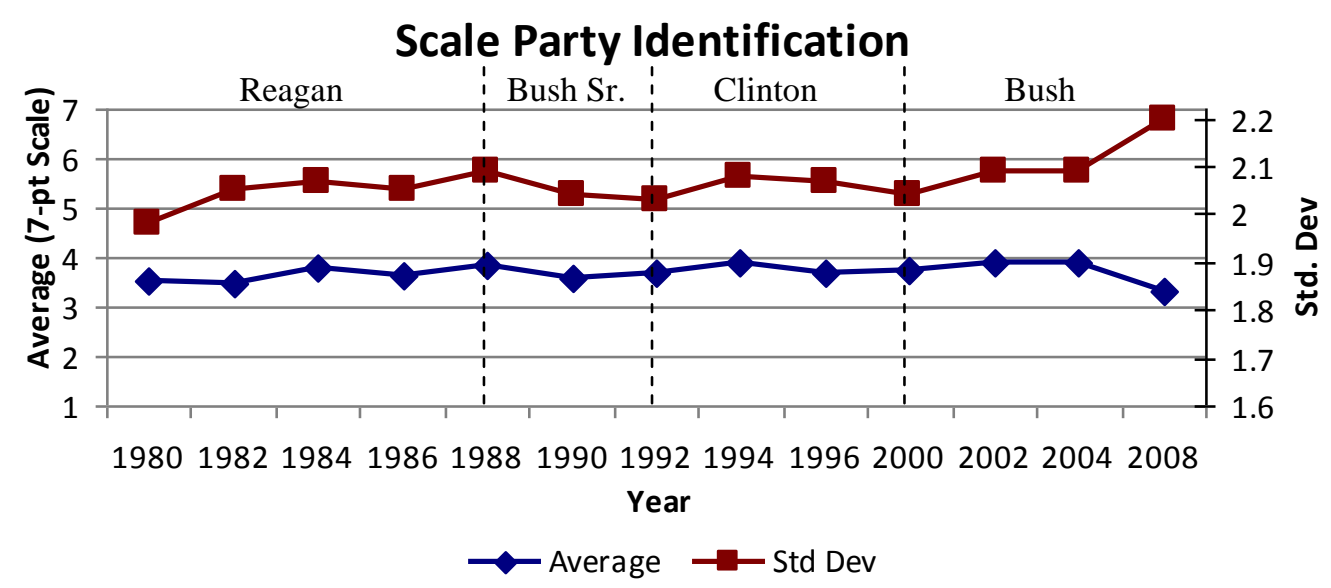

\begin{tabular}{lcc}
\hline Year & Average & Std Dev \\
\hline 1980 & 3.52 & 1.98 \\
1982 & 3.45 & 2.05 \\
1984 & 3.77 & 2.07 \\
1986 & 3.62 & 2.05 \\
1988 & 3.82 & 2.09 \\
1990 & 3.59 & 2.04 \\
1992 & 3.7 & 2.03 \\
1994 & 3.92 & 2.08 \\
1996 & 3.68 & 2.07 \\
2000 & 3.73 & 2.04 \\
2002 & 3.88 & 2.09 \\
2004 & 3.87 & 2.09 \\
2008 & 3.32 & 2.20 \\
\hline
\end{tabular}

\section{Determinants of the Scale Party Identification Variable}

Since political party affiliation also plays a significant role in determining an individual's defense spending preferences, I have run a regression to determine which of my variables of interest have strong influence over scale party identification. Similar to the Isolationist regression in Table 2, I used the scale party identification variable as the 
dependent variable and regressed the other main variables of interest upon the isolationist variable. The results are listed in Table 3 with the statistically significant (P-values < $10 \%$ ) variables in bold:

Table 3: Scale Party Identification Regression

\begin{tabular}{|c|c|c|c|c|}
\hline Independent Variables & Coef. & St. Err. & T-Value & P-Value \\
\hline isolationist & -0.2657 & 0.035 & -7.65 & 0.000 \\
\hline econstake & 0.0000 & 0.000 & 0.23 & 0.819 \\
\hline married & 0.2647 & 0.037 & 7.18 & 0.000 \\
\hline female & -0.2744 & 0.040 & -6.93 & 0.000 \\
\hline age & -0.0072 & 0.001 & -5.85 & 0.000 \\
\hline educ & 0.1449 & 0.017 & 8.57 & 0.000 \\
\hline unemployed & 0.0070 & 0.063 & 0.11 & 0.912 \\
\hline retired & -0.0783 & 0.077 & -1.02 & 0.309 \\
\hline notworking & 0.1891 & 0.047 & 4.00 & 0.000 \\
\hline black & -1.7063 & 0.038 & -45.43 & 0.000 \\
\hline asian & -0.1378 & 0.131 & -1.05 & 0.293 \\
\hline nativeamer $n$ & -0.1913 & 0.092 & -2.08 & 0.038 \\
\hline hispanic & -0.9265 & 0.061 & -15.29 & 0.000 \\
\hline otherrace & -1.1981 & 0.285 & -4.20 & 0.000 \\
\hline fy1980 & -0.2592 & 0.069 & -3.73 & 0.000 \\
\hline fy1984 & 0.0441 & 0.079 & 0.56 & 0.579 \\
\hline fy1986 & -0.0160 & 0.074 & -0.22 & 0.829 \\
\hline fy1988 & 0.1260 & 0.063 & 2.01 & 0.044 \\
\hline fy1990 & -0.1947 & 0.077 & -2.53 & 0.011 \\
\hline fy1992 & -0.0621 & 0.058 & -1.06 & 0.288 \\
\hline fy1994 & 0.1350 & 0.065 & 2.07 & 0.039 \\
\hline fy1996 & -0.0636 & 0.065 & -0.98 & 0.327 \\
\hline fy2000 & -0.0002 & 0.081 & 0.00 & 0.998 \\
\hline fy2004 & 0.1834 & 0.071 & 2.58 & 0.010 \\
\hline securitymoms & -0.0501 & 0.058 & -0.86 & 0.390 \\
\hline retiredWomen & 0.2120 & 0.093 & 2.28 & 0.023 \\
\hline cons & 2.6044 & 0.107 & 24.41 & 0.000 \\
\hline
\end{tabular}

As expected, isolationist is a statistically significant variable with the negative sign indicating that isolationists are less likely to be Republican with all else equal. 
Being married and increasing education have a positive effect on the likelihood of an individual being a Republican. With the exception of Asian, the race variables are all statistically significant and have a negative coefficient indicating that being Black, Hispanic, Native American, or Other Race makes you less likely to be a Republican than a Caucasian person holding all else equal.

\section{Economic Stake Variable}

The economic stake variable is included to control for the amount an individual stands to gain by having more defense spending in his or her own state. Most likely, a respondent will have a higher opinion of defense spending if they see federal tax dollars going towards creating jobs within their home state. The variable is based off the economic stake variable used in the Bartels paper, but with updated figures for recent years. $^{7}$

To create the variable, I used the yearly Almanac of American Politics to pull the share of the federal tax burden for the individual states as well as the share of federal outlays for the Department of Defense (DOD) per individual state. I then divided the national DOD outlays by the total Federal outlays and arrived at the percentage of taxes spent on Defense. By multiplying this percentage by the amount each state paid in Federal taxes, I was able to approximate the DOD tax burden per state. Finally, by subtracting the state's DOD tax burden from the state's share of the Federal outlay for DOD and dividing by the state's population, I was able to derive the economic benefit

\footnotetext{
${ }^{7}$ Bartels, 1994.
} 
variable.

For instance, in 1986, Alabama received $\$ 2.98$ billion in Federal outlays for defense. Alabama paid $\$ 8.29$ billion in taxes, of which $\$ 2.26$ billion was spent on Defense (27.3\% in 1986). ${ }^{8}$ Therefore, the state netted $\$ 720$ million in 1986 . With a population of 3.99 million, per capita economic stake was $\$ 180$.

The Almanac of American Politics stopped reporting state level Federal Expenditures for Defense in 1992, so the following year's data was aggregated from The Tax Foundation and USGovernmentSpending.org. See Appendix and Table 7 for further explanation of this variable.

\section{Demographic and Interaction Variables}

\section{Marital Status Variable}

The marital status variable consists of 22,731 responses to the ANES survey in the years of my study. I recoded those who answered divorced, separated, never married, or widowed to 0 in order to create a dummy variable for being married. $53.86 \%$ of the respondents were married while 46.14 were considered not married.

\section{Gender Variable}

22,731 respondents answered the gender question in the ANES survey. I created a dummy variable for female and recoded all males as 0 . Those who did not respond to

\footnotetext{
${ }^{8}$ Barone, 1972.
} 
the survey, or refused to answer were coded as missing. Females comprised $55.5 \%$ of the survey sample while males made up the remaining $45.5 \%$.

\section{Age Variable}

In the ANES CDF data (years 1980 - 2004), individuals give their age as a number between 18 and as high as 98 years old. However, in the 2008 data, individuals over the age 90 were grouped together into the "90 and above" category. Correspondingly, I recoded the CDF data to adjust all above 90 responses to 90 in order to create a matching group for "90 and above" in the combined dataset. The average age of the sample is 45.7 years old.

\section{Education Variable}

Once again, the data in the CDF and the 2008 survey differed significantly and required recoding to combine the two datasets. The $\mathrm{CDF}$ offered a variable that broke education down into six categories. For the purposes of this study, I combined the six categories into the following four categories:

1. No high school diploma

2. High school diploma or equivalency

3. Some college, no degree; junior college or associate's degree

4. Bachelor degree or above

From the 2008 data, I combined two separate variables in order to have consistency between the two datasets. The first variable was only asked of those whose highest year of education was between $0-12$ and it determined whether or not the 
respondent was a high school graduate. Those who answered no were coded as "1" to match the CDF, those who answered yes were coded as 2 .

The second variable was only used for those respondents who had 13 or more years of education. The respondents' options included associate's degree, bachelor's degree, master's degree, $\mathrm{PhD}, \mathrm{JD}, \mathrm{MD}$ and a myriad of other degrees. I coded the associate's degrees as " 3 " and all of the bachelor's degrees or higher as " 4 ”. The results of the education variable recoding can be seen in Chart 4 below:

$\underline{\text { Chart } 4 \text { Average Education from } 1980-2008}$

\section{Education}

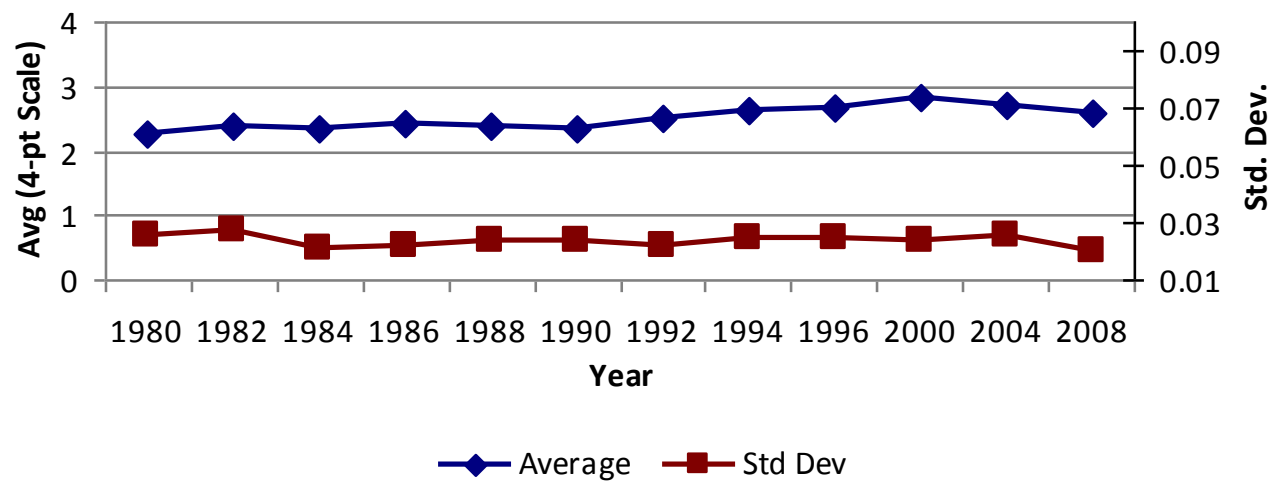

\begin{tabular}{lcc}
\hline Year & Average & Std Dev \\
\hline 1980 & 2.26 & 0.026 \\
1982 & 2.39 & 0.028 \\
1984 & 2.35 & 0.021 \\
1986 & 2.42 & 0.022 \\
1988 & 2.40 & 0.023 \\
1990 & 2.36 & 0.024 \\
1992 & 2.51 & 0.021 \\
1994 & 2.61 & 0.025 \\
1996 & 2.69 & 0.025 \\
2000 & 2.82 & 0.023 \\
2004 & 2.71 & 0.025 \\
2008 & 2.58 & 0.020 \\
\hline
\end{tabular}




\section{Employment Status Variables}

Since the employment status was a non-ordinal variable, I recoded the variable to create dummy variables for being retired, unemployed and not working. The baseline variable (set to 0) was "currently employed". The "notworking" dummy variable includes homemakers and students, while the unemployed variable covers those who have been laid off that are seeking work as well as those who are not seeking work. There were 22,780 responses for this variable and the results are detailed in Figure 5 below:

Figure 5 Employment Status Descriptive Statistics

\begin{tabular}{lrr} 
& Number of respondents & Percentage \\
Currently employed & 14,102 & $61.9 \%$ \\
Unemployed & 1,298 & $5.7 \%$ \\
Not working & 3,766 & $16.5 \%$ \\
Retired & 3,614 & $15.9 \%$ \\
\cline { 2 - 3 } & 22,780 & $100.0 \%$
\end{tabular}

\section{Race Variables}

The race variable was also a non-ordinal variable, so I recoded it to create dummy variables indicating different races. I used Caucasian as the baseline and then created dummy variables for Black, Asian, Native American, Hispanic and single dummy for those listed as "other" within the ANES data. There were 22,654 responses for this variable and the results are detailed in Figure 6: 
Figure 6 Race Descriptive Statistics

\begin{tabular}{lrr} 
& Number of respondents & Percentage \\
Caucasian & 16,924 & $74.7 \%$ \\
Black & 3,160 & $13.9 \%$ \\
Asian & 318 & $1.4 \%$ \\
Native American & 631 & $2.8 \%$ \\
Hispanic & 1,567 & $6.9 \%$ \\
Other Races & 54 & $0.2 \%$ \\
\hline Total & 22,654 & $100.0 \%$
\end{tabular}

Interaction Variables

Figure 7 details the descriptive statistics of the two interaction variables. Both variables were created from dummy variables already detailed above. Security Moms was calculated by multiplying female * married. While this does not control for age of the female or whether or not she has had children, it is still a suitable proxy and will be detailed more in the results section. The retired women interaction variable was created by multiplying the female dummy variable by the retired dummy variable. On average, security moms account for nearly $14 \%$ of the sample population while retired women account for $8.5 \%$ of the sample. 
$\underline{\text { Figure } 7 \text { Interaction Variable Descriptive Statistics }}$

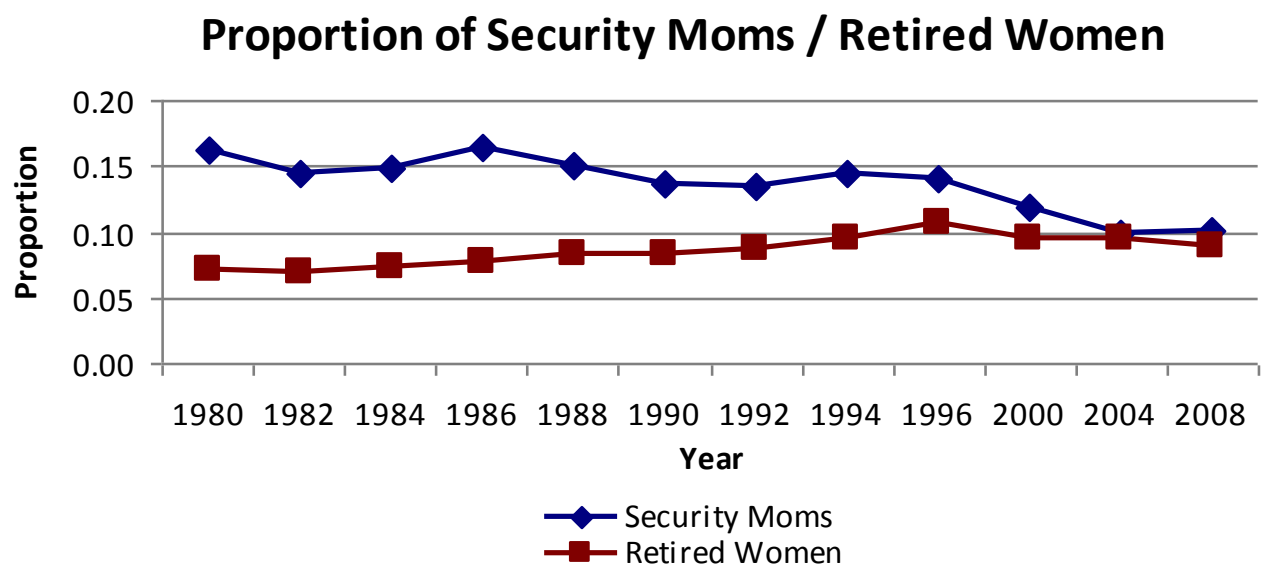

\begin{tabular}{lrr} 
& Number of respondents & Percentage \\
Retired Women & 1,939 & $8.5 \%$ \\
Non-Retired Women & 20,841 & $91.5 \%$ \\
\hline Total & 22,780 & $100.0 \%$ \\
1 Interaction of Retired and Female = Retired Women &
\end{tabular}

\begin{tabular}{lrr} 
& Number of respondents & Percentage \\
Security Moms & 3,128 & $13.8 \%$ \\
Non-Security Moms & 19,603 & $86.2 \%$ \\
\hline Total & 22,731 & $100.0 \%$
\end{tabular}

1 Interaction of Female and Married = Security Moms 


\section{Chapter V. Results}

As expected from the previous literature, Isolationist, Scale Party ID, and

Economic Stake were all statistically significant and displayed effects in the expected direction. Table 4 describes the results of the main regression of interest with Defense Spending Preferences as the dependent variable.

Table 4: Defense Spending Preferences Regression

\begin{tabular}{|c|c|c|c|c|}
\hline Independent Variables & Coef. & St. Err. & T-Value & P-Value \\
\hline isolationist & -0.3072 & 0.032 & -9.57 & 0.000 \\
\hline scalepartyid & 0.1782 & 0.006 & 28.64 & 0.000 \\
\hline econstake & 0.0001 & 0.000 & 3.43 & 0.001 \\
\hline married & 0.1252 & 0.030 & 4.23 & 0.000 \\
\hline female & -0.2349 & 0.034 & -6.92 & 0.000 \\
\hline age & 0.0046 & 0.001 & 4.43 & 0.000 \\
\hline educ & -0.2490 & 0.014 & -18.20 & 0.000 \\
\hline unemployed & 0.0733 & 0.065 & 1.13 & 0.260 \\
\hline retired & -0.1485 & 0.059 & -2.51 & 0.012 \\
\hline notworking & 0.0362 & 0.041 & 0.89 & 0.373 \\
\hline black & 0.0559 & 0.048 & 1.18 & 0.240 \\
\hline asian & -0.0914 & 0.104 & -0.88 & 0.378 \\
\hline nativeamer $n$ & 0.2478 & 0.080 & 3.09 & 0.002 \\
\hline hispanic & 0.1251 & 0.057 & 2.19 & 0.028 \\
\hline otherrace & 0.0129 & 0.258 & 0.05 & 0.960 \\
\hline fy1980 & 1.0697 & 0.060 & 17.87 & 0.000 \\
\hline fy1984 & -0.1949 & 0.068 & -2.87 & 0.004 \\
\hline fy1986 & -0.3384 & 0.065 & -5.24 & 0.000 \\
\hline fy1988 & -0.1974 & 0.055 & -3.61 & 0.000 \\
\hline fy1990 & -0.5842 & 0.065 & -8.93 & 0.000 \\
\hline fy1992 & -0.5960 & 0.050 & -11.92 & 0.000 \\
\hline fy1994 & -0.4113 & 0.054 & -7.63 & 0.000 \\
\hline fy1996 & -0.0426 & 0.053 & -0.80 & 0.425 \\
\hline fy2000 & 0.6393 & 0.078 & 8.23 & 0.000 \\
\hline fy2004 & 0.4612 & 0.058 & 7.96 & 0.000 \\
\hline securitymoms & 0.0636 & 0.047 & 1.35 & 0.178 \\
\hline retiredWomen & 0.2799 & 0.070 & 4.01 & 0.000 \\
\hline _cons & 3.9725 & 0.081 & 48.93 & 0.000 \\
\hline
\end{tabular}


The age and education variables also displayed the expected significance and directional effects - increased education decreases the amount one wants to spend on defense holding all else equal because educated people would rather spend money on domestic priorities such as healthcare. ${ }^{9}$ However, increased age increases the amount one wants to spend on defense. The married variable (whose coefficient needed to be adjusted for the effect of the security moms interaction variable, was also statistically significant and had an impact of positive .2048 .

While there is no prior literature to support these findings, Native American and Hispanic were also statistically significant and both had positive effects on defense spending preferences. Native Americans make up nearly $3 \%$ of the sample and Hispanics account for almost $7 \%$ so their statistical significance cannot be discounted due to lack of observations.

Also of interest were the statistical significance of retired women and the unanticipated positive effect on defense spending preferences. The statistically significant female and retired variables had an impact of -0.1563 and 0.0069 respectively after correcting for the impact of the retired $*$ women and married $*$ women interaction variables. As an interaction variable, retired women are still statistically significant, and had a positive impact on defense spending preferences by 0.2799 . As we shall see in the section titled "The Changing Determinants of Defense Spending Preferences through Time," however, when the data is broken down into individual decades, the retired variable is not statistically significant at any conventional level.

\footnotetext{
${ }^{9}$ Wong, 2007.
} 


\section{The Statistical Insignificance of Security Moms}

According to pollsters from both political parties, "security moms" became an important and targetable voting block in the 2004 election. They were defined as middle income, middle-aged mothers who were particularly concerned with the war in Iraq, domestic terrorism and their effects on families and children. ${ }^{10}$ In order to control for this effect in my regressions, I used the "Security Moms" interaction variable and found it to be insignificant in the overall model and only significant in the 1990's regression when broken down by decades as you can see Table 5 below. Some analysts and pundits thought the effect of the security mom voting block was being overplayed. Specifically, they claimed that there were some distinctions in the way women with children and women without children vote, but that the distinctions primarily regard domestic social issues and not national defense. ${ }^{11}$

While there are limitations on the security moms variable - such as the inability to control for the age of the women in the interaction variable - the lack of statistical significance seems to indicate that the "security mom" voting block did not have an impact in the 2004 election and that both campaigns would have been better off targeting a different segment of the electorate. That being said, the security mom variable was statistically significant in the 1990s and had a positive effect on the married women's defense spending preferences. This particular "decade outcome" for security moms is interesting because the effect of being female on defense spending preferences in the 1990s is negative (-.1332), while being married is insignificant, yet the interaction is

\footnotetext{
${ }^{10}$ Klein, 2003.

${ }^{11}$ Elder, 2007.
} 
positive. A somewhat counterintuitive explanation could lie in the relative calm of the 1990s. Perhaps married women who were worried about their children's safety thought that the best defense in peaceful times was a well funded military. In contrast, in the 1980s and 2000s the U.S. was already spending heavily on defense and therefore security moms did not exhibit any different defense spending preferences than unmarried women.

\section{Changing Determinants of Defense Spending Preferences through Time}

In order to see the changing determinants of defense spending preferences, I broke the dataset down into its respective decades to create three new datasets. I then ran the same regression using the same variables from the main regression. I used the first year in each dataset as the baseline and then controlled for the remaining years with dummy variables. While all individual year variables were statistically significant, the results were not displayed on the following table in order to reduce the amount of data on each table. Table 5 shows the percent change from the 1980s to the 1990s: 
Table 5: Change in Defense Spending Preferences Determinants from the 1980s - 1990s

\begin{tabular}{|c|c|c|c|c|c|}
\hline \multirow[b]{2}{*}{ Independent Variables } & \multicolumn{2}{|c|}{ 1980s } & \multicolumn{2}{|c|}{ 1990s } & \multirow[b]{2}{*}{$\%$ Change } \\
\hline & Coef. & P-Value & Coef. & P-Value & \\
\hline isolationist & -0.4556 & 0.000 & -0.2533 & 0.000 & $44.4 \%$ \\
\hline scalepartyid & 0.1771 & 0.000 & 0.1718 & 0.000 & $-3.0 \%$ \\
\hline econstake & 0.0001 & 0.060 & 0.0001 & 0.023 & $-3.9 \%$ \\
\hline female & -0.2379 & 0.000 & -0.2319 & 0.000 & $2.5 \%$ \\
\hline married & 0.2010 & 0.001 & 0.0659 & 0.193 & $\mathrm{n} / \mathrm{a}$ \\
\hline age & -0.0001 & 0.932 & 0.0065 & 0.000 & $\mathrm{n} / \mathrm{a}$ \\
\hline educ & -0.2776 & 0.000 & -0.2636 & 0.000 & $5.0 \%$ \\
\hline unemployed & 0.0219 & 0.821 & 0.1134 & 0.169 & $\mathrm{n} / \mathrm{a}$ \\
\hline retired & -0.1194 & 0.196 & -0.0913 & 0.245 & $\mathrm{n} / \mathrm{a}$ \\
\hline notworking & 0.0752 & 0.228 & 0.0406 & 0.464 & $\mathrm{n} / \mathrm{a}$ \\
\hline black & -0.2197 & 0.002 & 0.1545 & 0.010 & $170.3 \%$ \\
\hline asian & -0.0705 & 0.727 & -0.0877 & 0.482 & $n / a$ \\
\hline nativeamer n & 0.2884 & 0.041 & 0.1364 & 0.205 & $n / a$ \\
\hline hispanic & -0.2643 & 0.001 & 0.2395 & 0.001 & $190.6 \%$ \\
\hline otherrace & -0.4861 & 0.059 & 0.2277 & 0.378 & $\mathrm{n} / \mathrm{a}$ \\
\hline securitymoms & -0.0582 & 0.485 & 0.1275 & 0.066 & $n / a$ \\
\hline retiredWomen & 0.2016 & 0.068 & 0.1885 & 0.037 & $-6.5 \%$ \\
\hline cons & 4.8016 & 0.000 & 3.7146 & 0.000 & $n / a$ \\
\hline
\end{tabular}

And, Table 6 details the percent change from the 1990s to the 2000s: 
Table 6: Change in Defense Spending Preferences Determinants from the 1990s - 2000s

\begin{tabular}{|c|c|c|c|c|c|}
\hline & \multicolumn{2}{|c|}{ 1990s } & \multicolumn{2}{|c|}{ 2000s } & \multirow[b]{2}{*}{ Change } \\
\hline Independent Variables & Coef. & P-Value & Coef. & P-Value & \\
\hline isolationist & -0.2533 & 0.000 & -0.3327 & 0.000 & $-31.3 \%$ \\
\hline scalepartyid & 0.1718 & 0.000 & 0.2010 & 0.000 & $17.1 \%$ \\
\hline econstake & 0.0001 & 0.023 & 0.0000 & 0.556 & $\mathrm{n} / \mathrm{a}$ \\
\hline female & -0.2319 & 0.000 & -0.2379 & 0.004 & $-2.6 \%$ \\
\hline married & 0.0659 & 0.193 & 0.0768 & 0.338 & $\mathrm{n} / \mathrm{a}$ \\
\hline age & 0.0065 & 0.000 & 0.0076 & 0.000 & $16.9 \%$ \\
\hline educ & -0.2636 & 0.000 & -0.2642 & 0.000 & $-0.2 \%$ \\
\hline unemployed & 0.1134 & 0.169 & 0.0428 & 0.744 & $\mathrm{n} / \mathrm{a}$ \\
\hline retired & -0.0913 & 0.245 & 0.0924 & 0.422 & $\mathrm{n} / \mathrm{a}$ \\
\hline notworking & 0.0406 & 0.464 & 0.1916 & 0.025 & $\mathrm{n} / \mathrm{a}$ \\
\hline black & 0.1545 & 0.010 & 0.0510 & 0.551 & $\mathrm{n} / \mathrm{a}$ \\
\hline asian & -0.0877 & 0.482 & -0.2631 & 0.159 & $\mathrm{n} / \mathrm{a}$ \\
\hline nativeamer $\sim \mathrm{n}$ & 0.1364 & 0.205 & 0.4002 & 0.014 & $\mathrm{n} / \mathrm{a}$ \\
\hline hispanic & 0.2395 & 0.001 & 0.0958 & 0.280 & $\mathrm{n} / \mathrm{a}$ \\
\hline otherrace & 0.2277 & 0.378 & 0.0226 & 0.932 & $\mathrm{n} / \mathrm{a}$ \\
\hline securitymoms & 0.1275 & 0.066 & 0.0098 & 0.928 & $\mathrm{n} / \mathrm{a}$ \\
\hline retiredWomen & 0.1885 & 0.037 & -0.0634 & 0.650 & $\mathrm{n} / \mathrm{a}$ \\
\hline cons & 3.7146 & 0.000 & 4.4240 & 0.000 & $\mathrm{n} / \mathrm{a}$ \\
\hline
\end{tabular}

Of interest is the coefficient on Scale Party Identification. From the 1980s to the 1990s, Scale Party Identification falls by 3 percent. However, from the 1990s to the 2000s, Scale Party Identification increases by over 17 percent which runs against earlier literature on this subject.

Also of interest is the wide swing in the isolationist variable including a $44 \%$ gain from the 1980 s to the 1990 s and a drop of $31 \%$ from the 1990 s to the 2000 s. This change signifies the expanding influence of being an isolationist on defense spending preferences in the 1990s and then a similarly large decline in influence of the isolationist variable in the 2000s. 
Finally, Black and Hispanic dummy variables swing from a negative influence to a positive influence on defense spending preferences from the 1980s to the 1990s and then both become statistically insignificant in the 2000s. This change in preferences could be related to the number of Blacks and Hispanics that were increasingly employed by the federal government in the 1990s. ${ }^{12}$ As these groups began to identify more with the government due to their employment status, they might also be more willing to put taxpayer dollars into defense.

${ }^{12}$ Bureau of Labor Statistics. 2010. 


\section{Chapter VI. Conclusions}

Earlier academic literature predicted that politics would have less effect on defense spending preferences in the post-cold war era and that this trend would continue into the future. As we have seen, this literature was only partially correct; however, in the 1990s the literature was not able to predict the large and statistically significant impact that political party identification would eventually have in the 2000s. Both Scale Party Identification and Isolationism made large turnarounds in the 2000s and are either as influential as, or even more influential, than they were in the 1980s.

The data also points towards different voter blocks that could potentially be targeted by political candidates seeking office or politicians already in office who wish to sell their defense policy ideas. As was previously mentioned, the hype about security moms in the 2004 election seems to have been overplayed. On the other hand, the statistical significance of retired women and the positive affect this group displays for defense spending preferences could indicate the rise of the security grandmothers. While the effect of being female is negative and the effect of being retired is slightly positive, the joint effect is positive, statistically significant, and one of the strongest variables included in my regression. The difficulty lies in targeting a politician's message to the particular group, retired women, without also targeting the individual female subset.

In closing, public opinion on defense spending preferences has gone through many unpredictable changes throughout the years. Closely following these changes can 
help policy makers more effectively enact their legislation and can help political candidates stay in touch with the mood of the populace they endeavor to serve. 


\section{APPENDIX}

\section{Table 7: Economic Stake Compilation Example 1984}

\author{
1984 National Outlays \\ 1984 DoD Outlays \\ $\%$ spent on Defense \\ $\$ 604,000,000,000$ * Federal expenditures amounting to $\$ 604 \mathrm{~B}$ \\ $\$ 178,248,000,000$ \\ $29.5 \%$
}

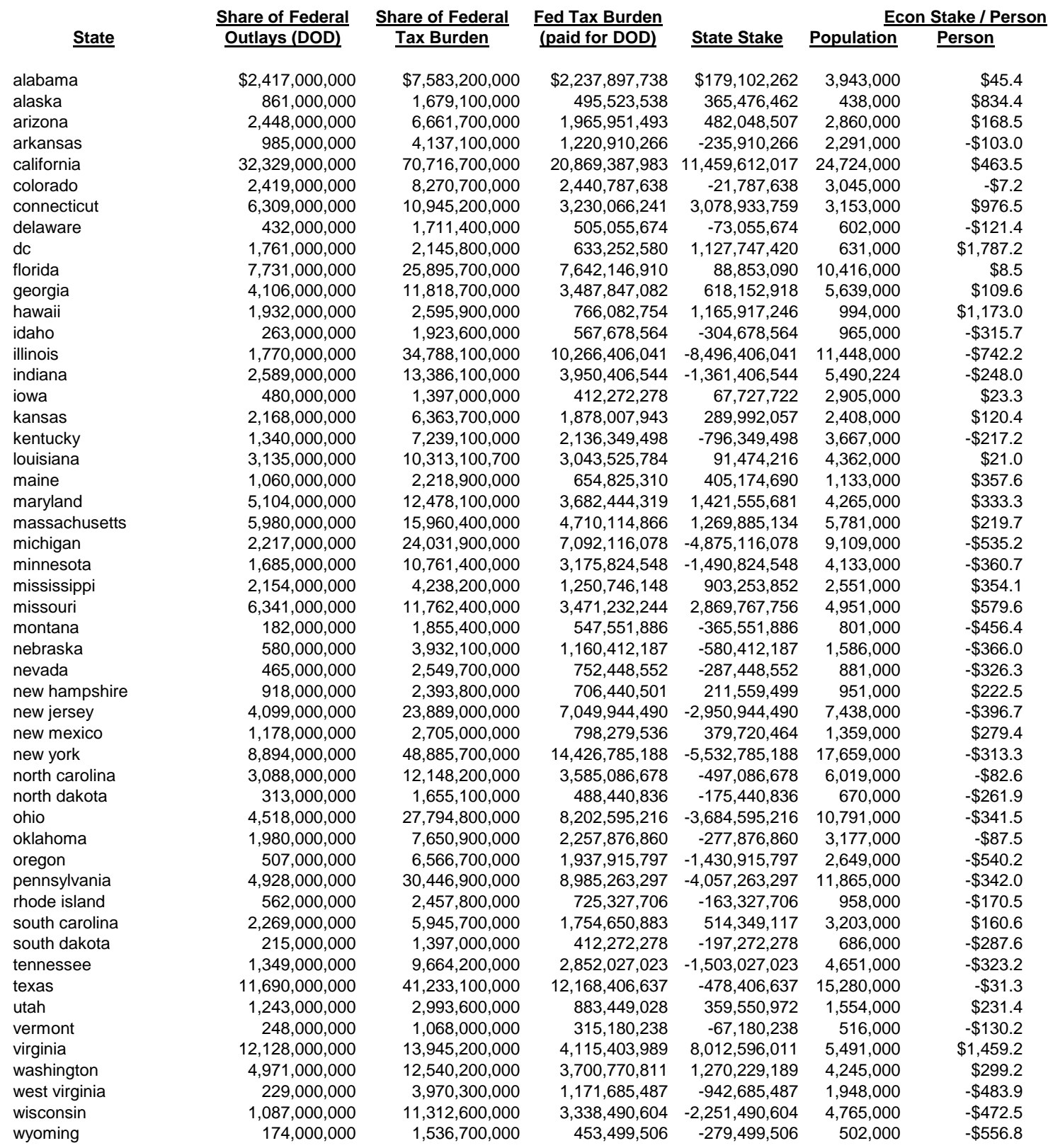


Table 8: Economic Stake

\begin{tabular}{|c|c|c|c|c|c|c|c|c|c|c|}
\hline & $\simeq$ & 1984 & 1986 & 1988 & 1990 & 1992 & 19 & $\underline{-}$ & {[} & 2004 \\
\hline 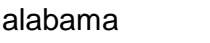 & $\$ 45$ & $\$ 234$ & $\$ 287$ & $\$ 341$ & $\$ 305$ & $\$ 269$ & $\$ 298$ & $\$ 298$ & $\$ 326$ & $\$ 599$ \\
\hline ask & $\$ 834$ & $\$ 828$ & $\$ 1,052$ & $\$ 1,275$ & $\$ 1,303$ & $\$ 1,331$ & $\$ 1,062$ & $\$ 1,062$ & $\$ 793$ & 1,15 \\
\hline במחק & $\$ 169$ & $\$ 363$ & $\$ 382$ & $\$ 401$ & $\$ 469$ & $\$ 537$ & $\$ 363$ & $\$ 363$ & $\$ 188$ & $\$ 667$ \\
\hline & $-\$ 103$ & $\$ 46$ & $-\$ 12$ & $-\$ 69$ & $-\$ 153$ & $-\$ 237$ & $-\$ 353$ & $-\$ 353$ & & 62 \\
\hline & $\$ 464$ & $\$ 804$ & $\$ 604$ & $\$ 404$ & $\$ 285$ & $\$ 167$ & $-\$ 116$ & $-\$ 116$ & $-\$ 398$ & $-\$ 2$ \\
\hline 0 & $-\$ 7$ & $\$ 88$ & $\$ 409$ & $\$ 731$ & $\$ 682$ & $\$ 632$ & $\$ 287$ & $\$ 287$ & $-\$ 59$ & $-\$ 139$ \\
\hline ticut & $\$ 977$ & $\$ 962$ & $\$ 622$ & $\$ 282$ & $\$ 130$ & $-\$ 23$ & $-\$ 442$ & $-\$ 442$ & $-\$ 862$ & $\$ 680$ \\
\hline & 1,787 & $\$ 1,662$ & $\$ 3,214$ & $\$ 4,767$ & $\$ 3,674$ & $\$ 2,581$ & $\$ 7,660$ & $\$ 7,660$ & $\$ 12,740$ & $\$ 15,341$ \\
\hline & $\$ 121$ & $-\$ 61$ & $-\$ 209$ & $-\$ 358$ & $-\$ 492$ & $-\$ 626$ & $-\$ 769$ & $-\$ 769$ & $-\$ 913$ & $-\$ 1,699$ \\
\hline .id & $\$ 9$ & $\$ 88$ & $\$ 6$ & $-\$ 76$ & $-\$ 105$ & $-\$ 134$ & $-\$ 323$ & $-\$ 323$ & $-\$ 511$ & $-\$ 686$ \\
\hline & $\$ 110$ & $\$ 401$ & $\$ 163$ & $-\$ 74$ & $-\$ 70$ & $-\$ 67$ & $-\$ 189$ & & & $-\phi 4$ \\
\hline & 1,173 & $\$ 1,569$ & $\$ 1,510$ & $\$ 1,452$ & $\$ 1,437$ & $\$ 1,422$ & $\$ 825$ & $\$ 825$ & 228 & $\$ 42$ \\
\hline & 316 & $-\$ 236$ & $-\$ 4$ & $\$ 228$ & $-\$ 54$ & $-\$ 336$ & 442 & 42 & 252 & $\$ 12$ \\
\hline & $-\$ 742$ & $-\$ 478$ & $-\$ 599$ & $-\$ 720$ & $-\$ 766$ & $-\$ 811$ & $-\$ 802$ & $-\$ 802$ & 792 & $-\$ 911$ \\
\hline a & $-\$ 248$ & $-\$ 21$ & $-\$ 214$ & $-\$ 408$ & $-\$ 382$ & $-\$ 356$ & $-\$ 433$ & & & $-\$ 476$ \\
\hline & $\$ 23$ & $-\$ 416$ & $-\$ 468$ & $-\$ 521$ & $-\$ 541$ & $-\$ 560$ & $-\$ 510$ & & $-\$ 459$ & $-\$ 54 \varepsilon$ \\
\hline & $\$ 120$ & $\$ 589$ & $\$ 283$ & $-\$ 23$ & $-\$ 74$ & $-\$ 125$ & $-\$ 292$ & $-\$ 292$ & $-\$ 459$ & $-\$ 342$ \\
\hline & $-\$ 217$ & $-\$ 81$ & $-\$ 140$ & $-\$ 199$ & $-\$ 210$ & $-\$ 221$ & $-\$ 136$ & $-\$ 136$ & 51 & $-\$ 136$ \\
\hline & $\$ 21$ & $\$ 21$ & $\$ 12$ & $\$ 4$ & $-\$ 6$ & $-\$ 15$ & $-\$ 28$ & $p 28$ & $-\$ 41$ & $-\$ 6 \varsigma$ \\
\hline & $\$ 358$ & $\$ 196$ & $\$ 110$ & $\$ 24$ & $\$ 113$ & $\$ 202$ & $\$ 7$ & $\$ 7$ & $-\$ 187$ & 183 \\
\hline & $\$ 333$ & $\$ 690$ & $-\$ 127$ & $-\$ 944$ & $-\$ 276$ & $\$ 393$ & $\$ 640$ & $\$ 640$ & $\$ 888$ & $\$ 1,983$ \\
\hline & $\$ 220$ & $\$ 583$ & $\$ 4$ & $\$ 221$ & $\$$ & 47 & 31 & & 19 & $-\$ 372$ \\
\hline & $-\$ 535$ & $-\$ 294$ & $-\$ 518$ & $-\$ 743$ & $-\$ 735$ & $-\$ 727$ & $-\$ 730$ & $-\$ 730$ & $-\$ 733$ & $-\$ 803$ \\
\hline & $-\$ 361$ & $-\$ 169$ & $-\$ 281$ & $-\$ 393$ & $-\$ 426$ & $-\$ 459$ & $-\$ 572$ & $-\$ 572$ & $\$ 684$ & $-\$ 983$ \\
\hline & & & $\$ 763$ & $\$ 787$ & & 36 & 31 & 1 & 77 & $\$ 20$ \\
\hline & $\$ 580$ & $\$ 631$ & $\$ 627$ & $\$ 622$ & 06 & $\$ 590$ & 89 & $\$ 389$ & 39 & 256 \\
\hline & $-\$ 456$ & $-\$ 285$ & $-\$ 299$ & $-\$ 314$ & $-\$ 317$ & $-\$ 320$ & $-\$$ & $-\$$ & 71 & $-\$ 334$ \\
\hline & $-\$ 366$ & $-\$ 201$ & $-\$ 227$ & $-\$ 253$ & $-\$ 248$ & $-\$ 244$ & & & $-\$ 626$ & $-\$ 769$ \\
\hline & $-\$ 326$ & $-\$ 1$ & $\$ 32$ & $\$ 205$ & $-\$ 57$ & $-\$ 318$ & 0 & & $-\$ 683$ & $-\$ 877$ \\
\hline & $\$ 222$ & $\$ 414$ & $\$ 80$ & $-\$ 255$ & 293 & $-\$ 331$ & $-\$ 559$ & & $-\$ 787$ & $-\$ 744$ \\
\hline & $-\$ 397$ & $-\$ 261$ & $-\$ 487$ & $-\$ 712$ & $-\$ 729$ & $-\$ 746$ & $-\$ 845$ & $-\$ 845$ & 9943 & $-\$ 1,113$ \\
\hline & & $\$ 384$ & $\$ 1,492$ & $\$ 2,601$ & $\$ 1$, & $\$ 403$ & & & & \\
\hline & $-\$ 313$ & $-\$ 137$ & $-\$ 360$ & $-\$ 583$ & & $-\$ 702$ & $-\$ 773$ & & 45 & $-\$ 1,119$ \\
\hline па & $-\$ 83$ & $\$ 22$ & $-\$ 20$ & $-\$ 61$ & $-\$ 103$ & $-\$ 145$ & $-\$ 344$ & $-\$$ & 3 & $-\$ 669$ \\
\hline & $-\$ 262$ & $-\$ 4$ & $-\$ 51$ & $-\$ 98$ & & 64 & & & & $-\$ 270$ \\
\hline & $-\$ 341$ & $-\$ 238$ & $-\$ 207$ & $-\$ 175$ & $-\$ 242$ & $-\$ 309$ & $-\$ 389$ & $-\$$ & & $-\$ 526$ \\
\hline & $-\$ 87$ & $-\$ 34$ & $\$ 4$ & $\$ 42$ & $\$ 26$ & $\$ 10$ & 778 & $-\$ 78$ & 66 & $-\$ 257$ \\
\hline & $-\$ 540$ & $-\$ 402$ & $-\$ 431$ & $-\$ 459$ & $-\$ 500$ & $-\$ 541$ & $-\$ 626$ & $-\$ 626$ & & $-\$ 838$ \\
\hline & & & & & & & & & & $-\$ 541$ \\
\hline & $-\$$ & & 72 & $-\$$ & & 63 & $-\$ 273$ & $-\$ 273$ & & $-\$ 830$ \\
\hline & $\$ 161$ & $\$$ & $\$ 389$ & $\$ 508$ & $\$ 366$ & $\$ 225$ & $\$ 73$ & $\$ 73$ & 78 & $-\$ 13$ \\
\hline & $-\$ 288$ & $-\$ 1$ & $-\$ 201$ & $-\$ 215$ & & $-\$ 253$ & $-\$ 326$ & $-\$ 326$ & $-\$ 399$ & $-\$ 561$ \\
\hline & $-\$ 323$ & & & & & $-\$ 360$ & $-\$ 142$ & $-\$ 142$ & & \\
\hline & $-\$ 31$ & & & & 77 & $\$ 78$ & $\$ 28$ & $\$ 28$ & 0 & $\$ 2$ \\
\hline & $\$ 231$ & $\$ 501$ & $\$ 647$ & $\$ 794$ & $\$ 634$ & $\$ 474$ & $\$ 141$ & $\$ 141$ & $-\$ 192$ & $-\$ 15$ \\
\hline & $\$ 130$ & $-\$ 228$ & $-\$ 353$ & $-\$ 478$ & & & & & & $-\$ 336$ \\
\hline & & $\$ 1,423$ & $\$ 1,991$ & $\$ 2,559$ & $\$ 2,197$ & & & & & $\$ 3,287$ \\
\hline IUII & $\$ 299$ & $\$ 468$ & $\$ 513$ & $\$ 558$ & $\$ 372$ & $\$ 186$ & $-\$ 134$ & $-\$ 134$ & $-\$ 454$ & $-\$ 319$ \\
\hline & $-\$ 484$ & $-\$ 405$ & $-\$ 388$ & $-\$ 371$ & $-\$ 391$ & $-\$ 412$ & $-\$ 361$ & $-\$ 361$ & $-\$ 311$ & $-\$ 304$ \\
\hline & $-\$ 473$ & $-\$ 359$ & $-\$ 468$ & $-\$ 577$ & & & & & $-\$ 692$ & $-\$$ \\
\hline & $-\$ 557$ & $-\$ 350$ & $-\$ 217$ & $-\$ 83$ & $-\$ 197$ & 310 & $-\$ 397$ & -\$397 & $-\$ 483$ & \\
\hline
\end{tabular}




\section{Missing Data for Defense Spending Preferences 1980 - 2008}

Variable of interest: Respondent Opinion: Should Government Cut Military Spending?

The missing code for this question was:

0 . Not applicable

Variable of interest: Respondent Placement: Defense Spending Scale

(1996,2004: Suppose these people are at one end of a scale, at point 1.)

(1996,2004: Suppose these people are at the other end, at point 7.) (2004: And, of course, some other people have opinions somewhere in between, at points $2,3,4,5$, or 6 ).

The missing codes for this question are as follows:

0 . Not applicable

NOTES:

This variable represents 7-point scale data from interviews conducted face-to-face. Respondents interviewed by telephone were asked a branching series and are not represented here.

Variable Years:

1980, 1982, 1984, 1986, 1988, 1990, 1992, 1994, 1996, 2000, 2004

Missing Data for Isolationist Variable 1980 - 2004

\section{MISSING_CODES:}

0. NA; no Pre IW; no Post IW; telephone IW (1984: see v.15); form B (1986); form A (1990); noncomparable question format (2000)

Variable years: 1980, 1984, 1986, 1988, 1990, 1992, 1994, 1996, 1998, 2000, 2002, 2004 


\section{References}

Barone, Michael, Ujifusa, Grant, Douglas, Matthews, "The Almanac of American Politics.” Boston. Gambit, 1972.

Bartels, Larry M. 1994. “The American Public's Defense Spending Preferences in the Post-Cold War Era." Political Opinion Quarterly. 58(4): 479-508. Retrieved December 2, 2009, from ABI/INFORM Global.

Bartels, Larry M. 1991. "Constituency Opinion and Congressional Policy Making: The Reagan Defense Buildup.” American Political Science Review. 85(2): 457-474.

Retrieved December 2, 2009, from ABI/INFORM Global.

Bureau of Labor Statistics (2010). "Economic News Release: Employment Situation.” http://www.bls.gov/news.release/empsit.toc.htm. Retrieved April 13, 2010.

Cox, D., \& Duffin, D.. (2008). Cold War, Public Opinion, and Foreign Policy Spending Decisions: Dynamic Representation by Congress and the President. Congress \& the Presidency, 35(1), 29-0_4. Retrieved December 16, 2009, from Social Science Module. (Document ID: 1470695701).

Eisenhower, Dwight D. (1961, January 17). Farewell address to the nation. Retrieved November 21, 2009 from Documents for the Study of American History Website: http://www.vlib.us/amdocs/texts/ddefarew.html 
Elder, Lauren, \& Greene, Steven. (2007). The Myth of "Security Moms" and "Nascar Dads": Parenthood, Political Stereotypes, and the 2004 Election*. Social Science Quarterly, 88(1), 1-19 Retrieved March 18, 2010, from Research Library Core. (Document ID: 1207770661).

Feldstein, Martin. (2007). The Underfunded Pentagon. Foreign Affairs, 86(2), 134-140. Retrieved December 16, 2009, from ProQuest Social Science Journals. (Document ID: 1274661821).

Griffin, John D. (2006). Electoral Competition and Democratic Responsiveness: A Defense of the Marginality Hypothesis. The Journal of Politics, Vol. 68, No. 4 (Nov., 2006), pp. 911-921. Retrieved December 3, 2009, from Research Library Core

Hartley, Thomas \& Russett, Bruce. Public Opinion and the Common Defense: Who Governs Military Spending in the United States? American Political Science Review, 86(4), 905-915, December 1992. Retrieved November 13, 2009.

Higgs, Robert \& Kilduff, Anthony. Public Opinion: A Powerful Predictor of U.S. Defense Spending. The Independent Institute, Defense Economics. October 1993.

Jacobs, Lawrence R \& Page, Benjamin I. (2005). Who Influences U.S. Foreign Policy? The American Political Science Review, 99(1), 107-123. Retrieved December 3, 2009, from Research Library Core. (Document ID: 1196172911). 
Klein, Joe. How Soccer Moms Became Security Moms. Time Magazine, Monday, February 10, 2003. Retrieved February 18, 2010, from www.time.com.

Ladd, Jonathan. (2007). Predispositions and Public Support for the President During the War on Terrorism. Public Opinion Quarterly, 71(4), 511-538. Retrieved December 7, 2009, from ABI/INFORM Global. (Document ID: 1396975171).

Mintz, Alex. (1992). The Political Economy of Military Spending in the United States. Routledge, New York, NY.

Mortensen, P.. (2009). Political Attention and Public Spending in the United.

States. Policy Studies Journal, 37(3), 435-455. Retrieved December 15, 2009, from ABI/INFORM Global. (Document ID: 1850871341).

Oscar Torres-Reyna, \& Robert Y Shapiro. (2002). The polls--trends: Defense and the military. Public Opinion Quarterly, 66(2), 279-303. Retrieved December 16, 2009, from ABI/INFORM Global. (Document ID: 137729121).

Russett, Bruce \& Hartley, Thomas, \& Murray, Shoon. (1994). The End of the Cold War, Attitude Change, and the Politics of Defense Spending. PS: Political Science \& Politics, 17 - 21. Retrieved December 16, 2009, from ABI/INFORM Global. 
Witko, Christopher. (2003). Cold war belligerence and U.S. public opinion toward defence spending. American Politics Research, 31(4), 379-403. Retrieved December 3, 2009, from Research Library Core. (Document ID: 353256181).

Wlezien, Christopher (1996). Dynamics of Representation: The Case of US Spending on Defence. British Journal of Political Science, Vol. 26, No. 1 (Jan., 1996), pp. 81-103. Retrieved December 3, 2009, from Research Library Core.

Wong, S. (2009). Public attitudes toward domestic and national security spending, before and after September 11, 2001. M.P.P. dissertation, Georgetown University, United States -- District of Columbia. Retrieved December 15, 2009, from Dissertations \& Theses @ Georgetown University - WRLC.(Publication No. AAT 1462592). 